Int. J. Dev. Biol. 56: 975-986 (2012)

doi: 10.1387/ijdb.120150jg

\title{
Amphibian interorder nuclear transfer embryos reveal conserved embryonic gene transcription, but deficient DNA replication or chromosome segregation
}

\author{
PATRICK NARBONNE and JOHN B. GURDON* \\ The Wellcome Trust/Cancer Research UK Gurdon Institute, The Henry Wellcome Building of Cancer and \\ Developmental Biology, University of Cambridge, Cambridge, U.K. and \\ Department of Zoology, University of Cambridge, Cambridge, U.K.
}

\begin{abstract}
Early interspecies nuclear transfer (iNT) experiments suggested that a foreign nucleus may become permanently damaged after a few rounds of cell division in the cytoplasm of another species. That is, in some distant species combinations, nucleocytoplasmic hybrid (cybrid) blastula nuclei can no longer support development, even if they are back-transferred into their own kind of egg cytoplasm. We monitored foreign DNA amplification and RNA production by quantitative PCR (qPCR) and RT-qPCR in interorder amphibian hybrids and cybrids formed by the transfer of newt (Pleurodeles waltl) embryonic nuclei into intact and enucleated frog (Xenopus laevis) eggs. We found a dramatic reduction in the expansion of foreign DNA and cell numbers in developing cybrid embryos that correlated with reduced gene transcription. Interestingly, expansion in cell numbers was rescued by the recipient species (Xenopus) maternal genome in iNT hybrids, but it did not improve $P$. walt I DNA expansion or gene transcription. Also, foreign gene transcripts, normalized to DNA copy numbers, were mostly normal in both iNT hybrids and cybrids. Thus, incomplete foreign DNA replication and/or chromosome segregation during cell division may be the major form of nuclear damage occurring as a result of nuclear replication in a foreign cytoplasmic environment. It also shows that the mechanisms of embryonic gene transcription are highly conserved across amphibians and may not be a major cause of cybrid lethality.
\end{abstract}

KEY WORDS: nucleocytoplasmic hybrid (cybrid), hybrid, interspecies nuclear transfer (iNT), nucleocytoplasmic incompatibility, triploid nuclear transfer embryos

\section{Introduction}

Shortly after the introduction of the technique of nuclear transfer (NT) in Rana pipiens frogs (Briggs and King, 1952), Moore was the first to report interspecies nuclear transfer (iNT) experiments, between $R$. pipiens and $R$. sylvatica (Moore, 1958). His major observations were that cybrid development proceeded normally until the late blastula stage, but that the embryos then arrested and expired, similar to what happened when enucleated eggs of one species were cross-fertilized with sperm of the other species (Moore and Moore, 1953). Moreover, after performing back-transfer experiments in which cybrid blastomere nuclei were transferred back into enucleated eggs of the nuclear species, he observed that these were no longer able to develop beyond the late blastula stage, suggesting that the nuclei were damaged by a few rounds of division in the foreign species cytoplasm (Moore, 1958). Similar results were later obtained using two Xenopus species, $X$. laevis and $X$. tropicalis (Gurdon, 1962). These early studies indicated that nuclear damage during cell division in a foreign cytoplasm could be a cause of cybrid developmental arrest, although the type and

\footnotetext{
Abbreviations used in this paper: Cybrid, nucleocytoplasmic hybrid; EGA, embryonic genome activation; iNT, interspecies nuclear transfer; iSCNT, interspecies somatic cell nuclear transfer; mtDNA, mitochondrial DNA; MY, million years; NT, nuclear transfer; qPCR, quantitative PGR; SCNT, somatic cell nuclear transfer; UV, ultraviolet.
}

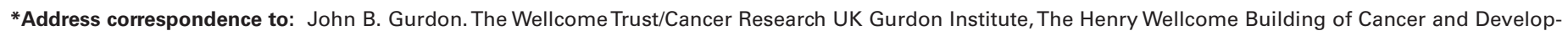
mental Biology, University of Cambridge, Tennis Court Road, Cambridge CB2 10N, United Kingdom.

Tel: +44-(0)-1223-334090. Fax: +44-(0)-1223-334089. e-mail: john.gurdon@gurdon.cam.ac.uk
}

Supplementary Material (podcast) for this paper is available at: http://dx.doi.org/10.1387/ijdb.120150jg

Final, author-corrected PDF published online: 5 February 2013.

ISSN: Online 1696-3547, Print 0214-6282

(C) 2013 UBC Press

Printed in Spain 
extent of damage remained unclear. It was later demonstrated that such kinds of irreversible nuclear damage does not occur in all lethal interspecific cybrids (Hennen, 1974), thereby indicating that other kinds of fatal nucleocytoplasmic incompatibilities exist between distantly related species. Indeed, there is now increasing evidence that a whole range of nucleocytoplasmic incompatibilities exists across species, and that these may include reprogramming, cellular and/or developmental incompatibilities (Narbonne et al., 2012a).

The possibility of an interspecific reprogramming incompatibility that would affect cybrid survival so far remains theoretical as the major reprogramming mechanisms and pluripotency factors appear to be highly conserved, at least across the class mammalia (Narbonne et al., 2012a; Rajarajan et al., 2012). Indeed, even if treatment with a deacetylase inhibitor (trichostatin A) improves some aspects of reprogramming in interspecies somatic cell nuclear transfer (iSCNT), much like it does in same-species somatic cell nuclear transfer (SCNT), it does not improve survival (Shi et al., 2008; Srirattana et al., 2008; Lee et al., 2010; Gómez et al., 2011). Reprogramming defects therefore occur in most iSCNT embryos, but these defects may not be different from those occurring in same-species SCNT embryos, hence they may not be due to an interspecies incompatibility. It nonetheless remains possible that some potential reprogramming incompatibilities in cybrids may be hidden by other fatal defects. Also, certain cybrid combinations may be more susceptible to suffer from reprogramming incompatibilities than others, for example due to a divergence in the way eggs demethylate sperm (or somatic nuclei) among some mammalian orders, such as between sheep and mice (Beaujean et al., 2004).

Cellular nucleocytoplasmic incompatibilities, such as those that generate permanent nuclear damage in some frog cybrid combinations (Moore, 1958; Gurdon, 1962), may exist in many cybrid cells and embryos. Indeed, in experiments where cells were isolated from cybrid embryos and grown in culture, in most cases they had a reduced proliferation and expansion capacity (Tecirlioglu et al., 2006; Sha et al., 2009; Narbonne et al., 2012b). Also, experiments involving cultured cybrid cells generated by cell fusion suggest that there may be a nucleo-mitochondrial incompatibility between species that leads to oxidative respiration defects in cybrid cells, the severity of which correlates with evolutionary distance (McKenzie et al., 2003). For example, it was found that mitochondrial DNA (mtDNA) from closely related non-human primates, including the chimpanzee and the gorilla, can rescue oxidative phosphorylation in mtDNA-less human cells, but not mtDNA from more distant primates, such as the orangutan (Kenyon and Moraes, 1997). The in vivo relevance of this phenomenon however remains unclear (Cannon et al., 2011).

Cybrid developmental incompatibilities may include defects in embryonic genome activation (EGA), if the recipient egg cytoplasm is unable to activate embryonic transcription in the foreign nucleus (Beyhan et al., 2007). Recent evidence however suggests that EGA is at least partially successful in several relatively distant and lethal cybrid embryos, in that the transcription of many embryonic genes is initiated normally (Wang et al., 2009, 2011; Fujimoto et al.,
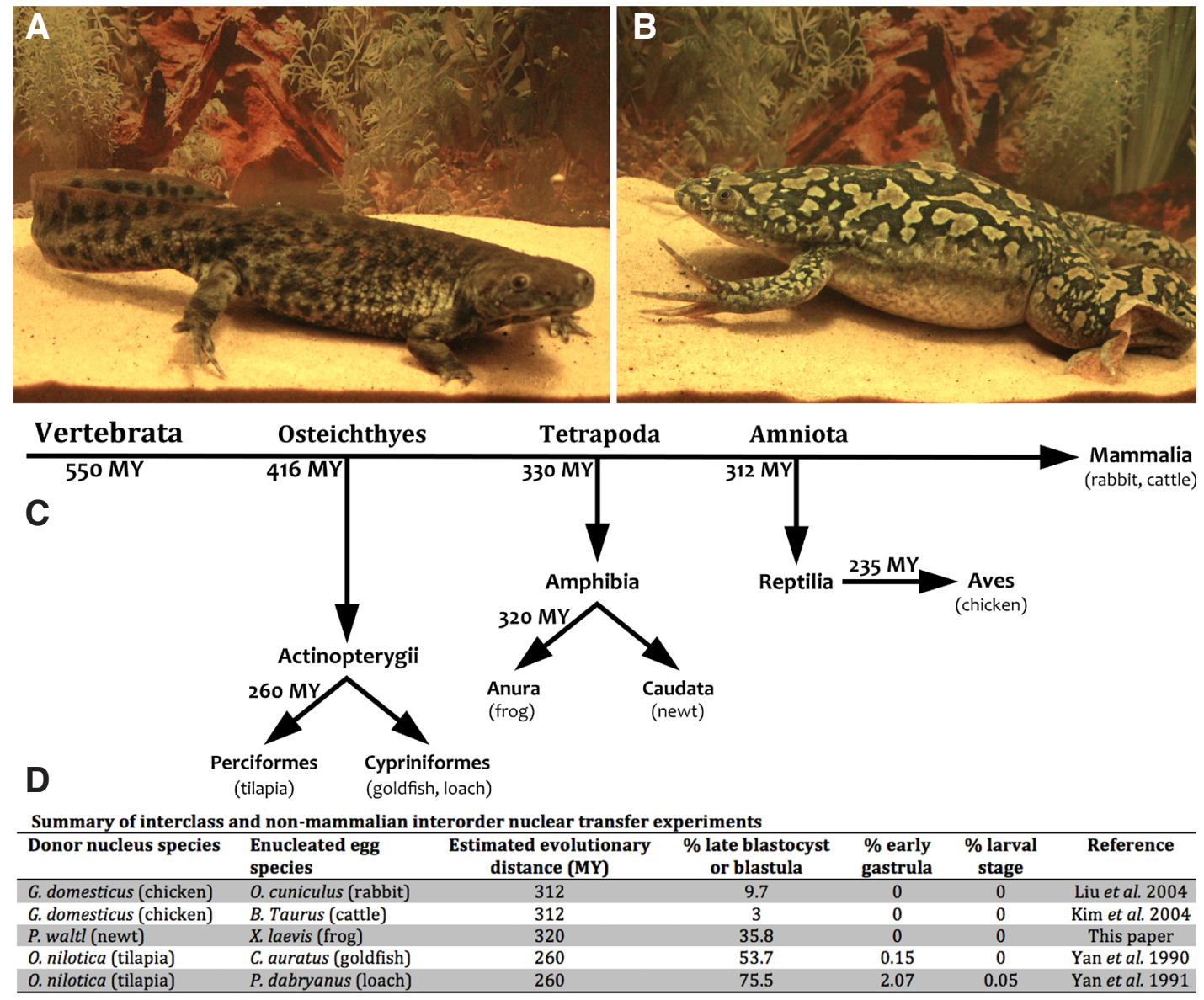

Fig. 1. Cybrid embryos formed by $P$. walt nuclei and $X$. laevis egg cytoplasm are possibly the most evolutionary distant ones ever reported. Adult P. waltl (A) and X. laevis (B) females are shown approximately at the same magnification. (C) A simplified evolutionary tree encompassing selected vertebrate superclasses (Osteichthyes, Tetrapoda, Amniota), classes (Actinopterygii, Amphibia, Reptilia, Aves, Mammalia) and orders (Perciformes, Cypriniformes, Anura, Caudata). Approximate divergence times (MY) are based on minimal divergence times estimated from fossil records (Janvier, 2006; Benton and Donoghue, 2007), except for the radiation of Actinopterygii ( 260 MY), which is the mean of estimates based on mtDNA and nuclear DNA divergence (Hurley et al., 2007), and for the separation of Anura and Caudata $1 \sim 320$ MY), which occurred within 10 MY following the appearance of Amphibia (Roelants et al., 2007). Adapted from (Nomiyama et al., 2011). (D) The developmental potential of the most distant inter-class and non-mammalian interorder cybrids reported. 
2010; Narbonne et al., 2011). Defects in gene expression however become apparent if the embryos are cultivated for longer durations (Fujimoto et al., 2010), but it is unclear whether this occurs secondarily to other reprogramming, cellular and/or developmental defects, or because of a genuine inability to maintain embryonic transcription.

A new form of developmental nucleocytoplasmic incompatibility has also recently been identified, and may occur when a gene's orthologs have different expression levels or patterns, or have different regulatory mechanisms, in related species. Examples of this come from studies in $X$. laevis and $X$. tropicalis, two frog species separated by approximately 50-65 million years (MY) (Evans et al., 2004; Roelants et al., 2007). Incubation of nuclei from one species in egg extracts from the other species results in nuclear and spindle expansion, the magnitude of which depends on the extract (cytoplasmic) species. This difference arises because a relatively small number of protein orthologs diverge in their concentrations or in their regulation in the two species. Indeed, the difference in nuclear expansion is dependent on the concentrations of two nuclear transport factors (Importin $\alpha$ and Ntf2), while spindle scaling is affected by the presence of an inhibitory phosphorylation site on a microtubule severing factor (Katanin) ortholog (Levy and Heald, 2010; Loughlin et al., 2011). It is however uncertain whether the aforementioned differences affect development in cybrid embryos made from these two species. It would nonetheless appear that an interspecific difference in the concentrations of a key embryonic transcription factor (Xbra) that is important in driving gastrulation movements might be detrimental to cybrid development. This occurs because the regulation of protein concentration in the early cybrid embryo is under maternal, cytoplasmic (rather than nuclear) control, which leaves cybrids with inappropriate protein concentrations to sustain development that could be promoted by their foreign nuclei (Narbonne et al., 2011). It is uncertain whether similar kinds of problems may occur in other cybrid combinations.

A large number of relatively distant cybrids formed by the combination of interspecific, intergeneric, interfamily and interorder placental mammal nuclei and egg cytoplasm have been described (Beyhan et al., 2007; Loi et al., 2011). In most combinations, blastocysts have been obtained, but embryo survival and development potential generally correlates inversely with evolutionary separation. The entire placental mammal lineage evolved over about 160 MY (Luo et al., 2011); very few highly divergent (>250 MY) non-mammalian interorder, or interclass cybrid embryos have been generated, and they remain poorly described (Fig. 1; Yan et al., 1990, 1991; Kim et al., 2004; Liu et al., 2004). Moreover, in these studies it was not demonstrated that the few animals that developed further were indeed genuine cybrids (without any nuclear DNA contribution from the recipient species). As the most subtle interspecies incompatibilities may become obvious in increasingly distant combinations, we have examined sequence-specific nucleic acid contents in an amphibian interorder cybrid, generated by the transfer of embryonic Pleurodeles walt/(Iberian ribbed newt) nuclei into enucleated and non-enucleated Xenopus laevis (African clawed frog) eggs. This is possibly the most evolutionarily divergent $(\sim 320$ MY) interspecific cybrid so far reported (Fig. 1).

\section{Results}

\section{P. walt to X. laevis nuclear transfer interorder cybrids form late blastulae}

To determine the extent with which the egg cytoplasm of one amphibian species can support the development that is promoted by the nucleus of a different order, we have transferred endoderm nuclei from $P$. walt embryos into $X$. laevis eggs whose nuclei had been previously inactivated using ultraviolet (UV) irradiation (Elsdale et al., 1960). These particular two species were chosen based on availability and their similar culture conditions and optimal growth temperature range. $X$. laevis eggs were chosen as recipients because of the well established NT methodology using this species' eggs (Elsdale et al., 1960). Embryonic endoderm is an efficient nuclear donor tissue for same-species NT in $X$. laevis and 30 to $45 \%$ of total nuclear transferred embryos commonly reach a late blastula stage (Gurdon, 1960). We presumed that tissue differentiation would follow similar rules in Pleurodeles (Picheral, 1962; Gallien et al., 1973), and thus we used this tissue as a nuclear donor in our experiments in order to minimize the effect of potential reprogramming incompatibilities between the two species. A relatively high percentage $(-35 \%)$ of the resulting $P->[X]$ (where the first and second capital italic letters represent the genus of the nuclear donor and recipient egg, respectively; the arrow $(->)$ indicates that the procedure for NT was carried out; and square brackets indicate that a component's nucleus had been inactivated) cybrids could develop until the late blastula stage, albeit they all had varying degrees of abnormality (Table 1; Fig. 2). No cybrid embryos were observed to begin gastrulation movements, and they instead arrested and died as late blastulae (Figs. 1-2). Interestingly, although we have not quantified this defect, the early cleavages in $P->[X]$ NT embryos were frequently delayed and abnormal or irregular, resulting in misshaped or unequal blastomeres (Fig. 2), which may be linked to defects in spindle

TABLE 1

\section{GRADE` OF NUCLEAR TRANSFER LATE BLASTULAE}

\begin{tabular}{|c|c|c|c|c|c|c|c|c|c|}
\hline NT (N) & $\mathbf{n}$ & 1 & 2 & $\mathrm{RCB}^{\S}(\%)$ & 3- $\left(\%^{*}\right)$ & $3(\% *)$ & $3+(\% *)$ & $4\left(\%{ }^{\star}\right)$ & $5(\% *)$ \\
\hline$X->[X]^{\mathrm{a}}(3)$ & 114 & 48 & 17 & $49(43.0)$ & $5(10.2)$ & $3(6.1)$ & 7 (14.3) & $20(40.8)$ & $14(28.6)$ \\
\hline$P->[X]^{\mathrm{b}}(5)$ & 288 & 104 & 81 & $103(35.8)$ & $46(44.7)$ & 39 (37.9) & 15 (14.6) & $3(2.9)$ & $0(0)$ \\
\hline$P->X^{c}(2)$ & 106 & 31 & 21 & $54(50.9)$ & $1(1.9)$ & $1(1.9)$ & $8(14.8)$ & $11(20.4)$ & $33(61.1)$ \\
\hline
\end{tabular}

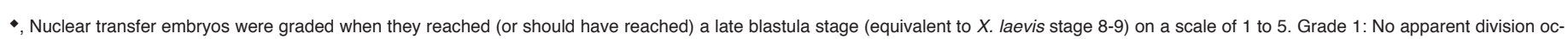

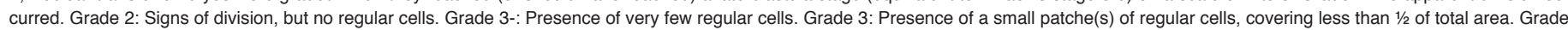

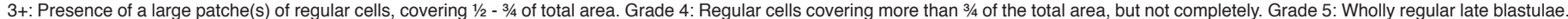

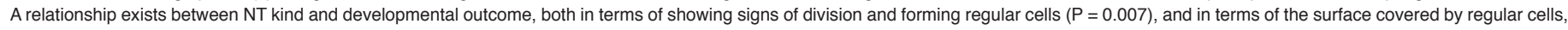
amongst the blastulae that contained regular cells $(P<0.001)$. Chi Square analysis.

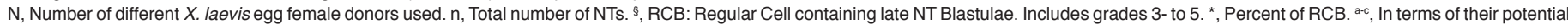

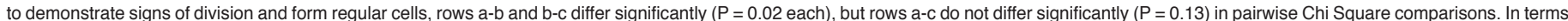

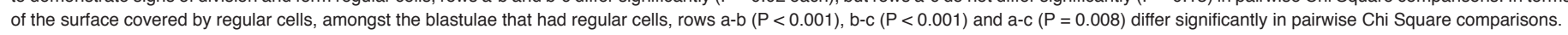


assembly and/or chromosome segregation (Wheatley et al., 1998). This also happened in same-species NT $(X->[X])$, but to a much lesser extent and magnitude (Fig. 2). These results indicate that the $X$. laevis egg cytoplasm is unable to sustain the full development that is promoted by a $P$. walt/ nucleus. On the other hand, it suggests that the $X$. laevis egg cytoplasm can recognize this very distantly related nucleus, such that a relatively high percentage of the resulting cybrid embryos can undergo multiple rounds of cell division and develop until a late blastula stage.

\section{Inherent inability of $\mathrm{X}$. laevis egg cytoplasm to replicate and/ or segregate P. waltl DNA}

To approximate the expansion in cell numbers in cybrid embryos, at the time where controls had reach the late blastula stage, we classified all the iNT embryos into one of five grades (Table 1). The results indicated that $P->[X]$ cybrid embryos showed a significantly reduced ability to undergo cleavage or form regular cells, when compared to $X->[X]$ controls (Table1). Similarly, amongst the cybrid embryos which formed regular cells, they covered a significantly smaller area of the late blastulae in $P->[X]$ than in $X->[X]$ controls (Table 1; Fig. 2). Therefore, we conclude that expansion in cell numbers is impaired in interorder cybrid embryos.

The abnormal cell divisions and reduced expansion in cell numbers in cybrid embryos could either arise as a result of the foreign nuclei or chromosomes interfering with the process of cell division in $X$. laevis cytoplasm, or because of a genuine incapacity of the $X$. laevis cytoplasm to efficiently replicate and/or divide cells carrying $P$. walt/ DNA or chromosomes. To test this, we have transferred endoderm nuclei from $P$. walt/ embryos into intact (nonenucleated) $X$. laevis eggs. Interestingly, when compared to $P->[X]$, the resulting $P$-> Xembryos formed significantly more blastulae that either showed signs of cleavage or had regular cells, and amongst blastulae that had regular cells, the area covered was significantly increased (Table 1; Fig. 2). The developmental success of $P->X$ hybrid embryos, in terms of the area of blastula stage embryos covered by regular cells, was significantly improved even compared to $X->[X]$ controls (Table 1; Fig. 2). These observations argue that $P$. walt/ chromosomes do not interfere with cell division promoted by the $X$. laevis egg cytoplasm.

We allowed several of the most regular $P->X$ late blastulae obtained to develop further, and to our surprise most of them survived through gastrulation and neurulation (Table 2), and formed
A

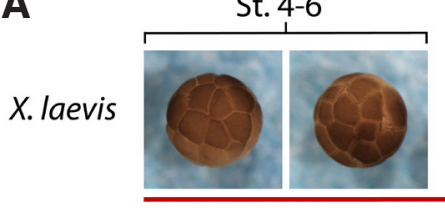

B

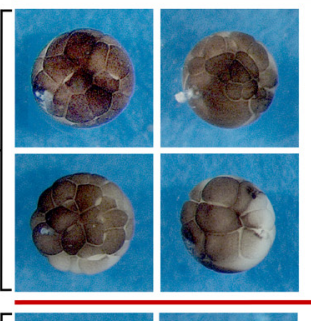

C

C $P \rightarrow[X]$

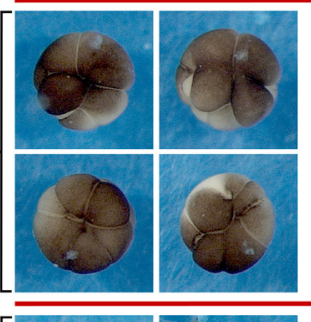

D

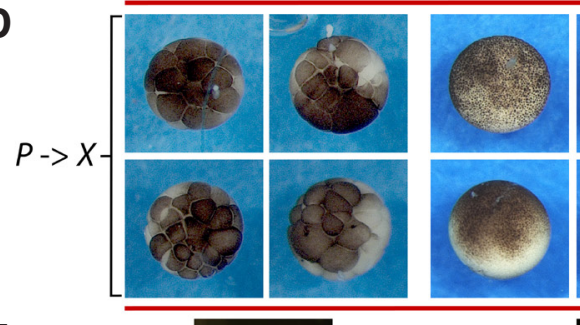

E P. walt I
St. 7-9

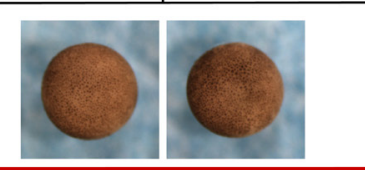

St. 31-34

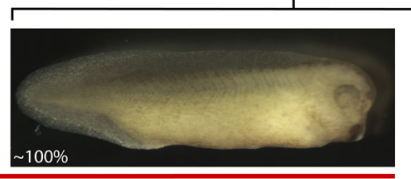

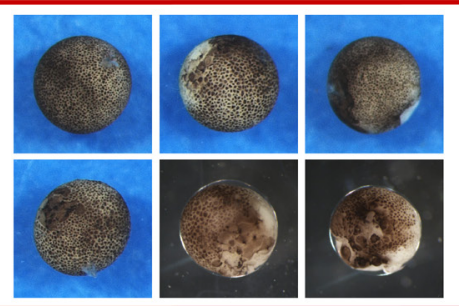
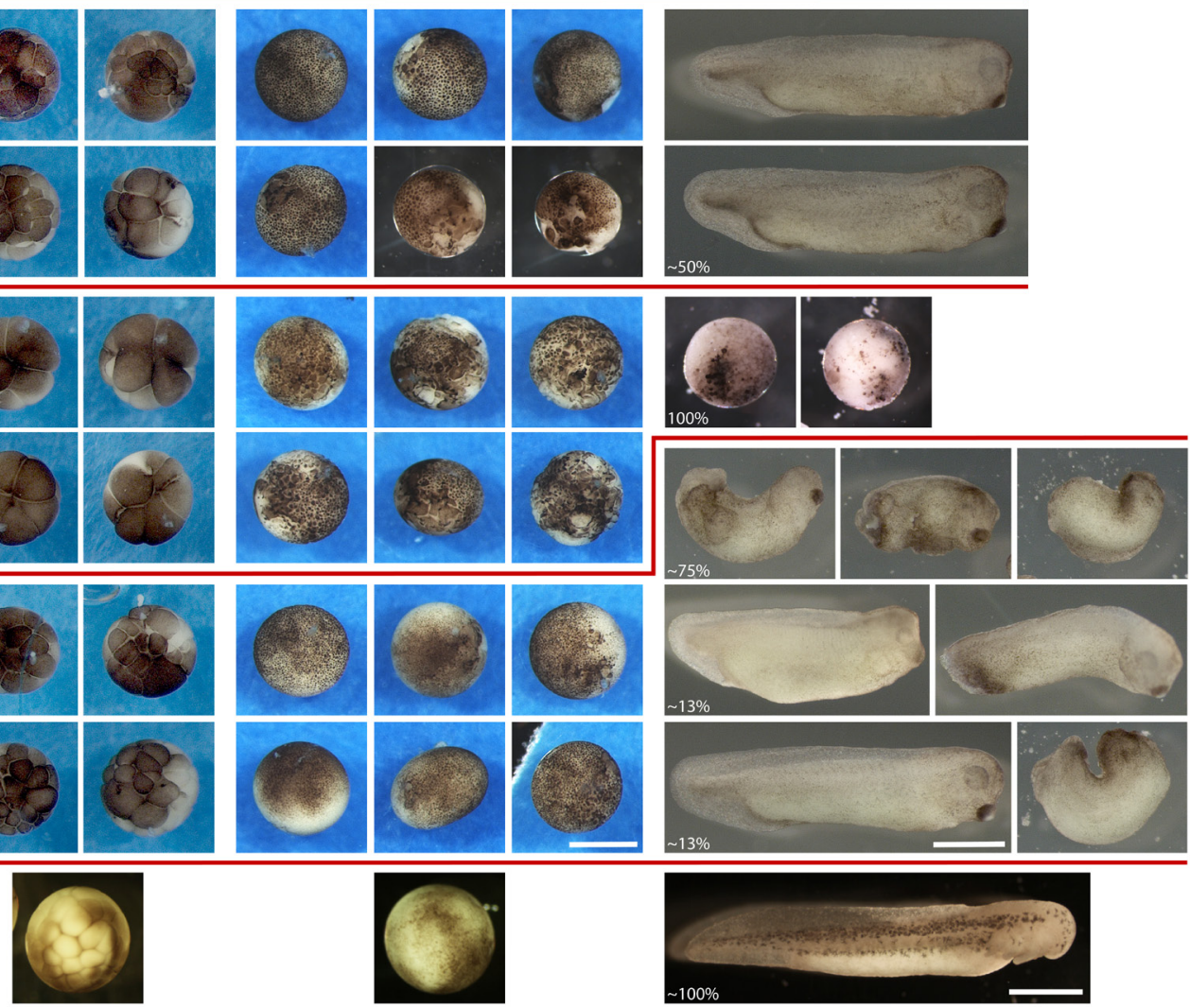

and various poorly-developed post neurulae (top and right-most panels in the St. 31-34 column; 75\% of Grade 5 St. 9 late blastulae). No obvious P. waltl-like morphological features were observed. (E) P. waltl diploid control naturally fertilized embryos. In each section, a range of 1-7 representative embryos is shown. Scale bars for all blastulae and X. laevis egg-based tailbud stage embryos: 1 mm; and P. waltl tailbud stage embryo: 2 mm. 
abnormal post-neurula stage embryos that ranged from poorly elongated, microcephalic post-neurulae, to haploid syndromelooking (Hamilton, 1963), or even perfectly normal, diploid-looking $X$. laevis late tailbud stage embryos (Fig. 2). Unlike all known hybrids, which show a phenotype that is intermediate between the two parental genomes, none of the $P$ - $>X$ embryos showed any obvious features that would make them resemble $P$. waltlembryos. These observation led us to suspect that $P$->Xembryos may either not contain $P$. walt/ DNA, and/or may not express $P$. walt/ genes. Thus we considered the possibility that the $X$. laevis egg cytoplasm may not be very efficient at replicating and/or segregating $P$. waltl chromosomes. If this was the case, it would suggest that the poor capacity of the $X$. laevis egg cytoplasm to promote the normal cell division and expansion of cells carrying $P$. walt/ nuclei in $P->[X]$ cybrids arises as a result of a genuine incapacity of the $X$. laevis cytoplasm to efficiently replicate and/or segregate $P$. walt/DNA or chromosomes.

To test this hypothesis, in a first instance, we looked at the chromosomal and nucleolar content in a small number of late neurula/early tailbud stage $P->X$ embryos that were sacrificed. Chromosomal spread analysis indicated that some cells in $P->X$ embryos unambiguously contained more than 18 chromosomes, the haploid $X$. laevis chromosomal complement, but no cells had 42 distinguishable chromosomes, the full complement that would be expected in this hybrid NT combination (Fig. 3). In Xenopus, nuclei contain up to one nucleolus per haploid genome, thus up to two nucleoli per diploid nucleus. In $P$. waltl, we observed up to four nucleoli per nucleus in diploid individuals (Fig. 4). In $P$-> X hybrids, there were up to three nucleoli/nucleus, albeit three occurred only in a very small proportion $(-0.4 \%)$ of the nuclei, and most had either one (65.5\%) or two (34\%) nucleoli (Fig. 4). Since haploid $X$. laevis embryos have only one nucleolus per nucleus (Narbonne et al., 2011), this suggests that at least some, but likely not all of the nucleolar organizing centres within the diploid $P$. walt genome initially transferred are still present and functionally recognized in many cells of late neurula/early tailbud stage $P->X$ hybrid embryos. These data together suggest that several cells in late neurula/early tailbud stage $P->X$ hybrid embryos likely contain an incomplete fraction of the $P$. walt/ diploid genome initially transferred.

To unambiguously assess the fate of the transferred $P$. walt genome in $P \rightarrow>[X]$ cybrid and $P \rightarrow>X$ hybrid embryos, we performed qPCR using both $X$. laevis and $P$. walt/specific primers for several genes with known nucleotide sequences, which we found on the NCBI nucleotide database. Amongst the selected $P$. walt genes, we chose three Hox genes located in different clusters, each of which are generally located on a different chromosome in vertebrates (Bailey et al., 1997). Thus, our analysis is expected to be representative of the behaviour of at least a few different chromosomes. To control and validate our approach, we first quantified gene copy
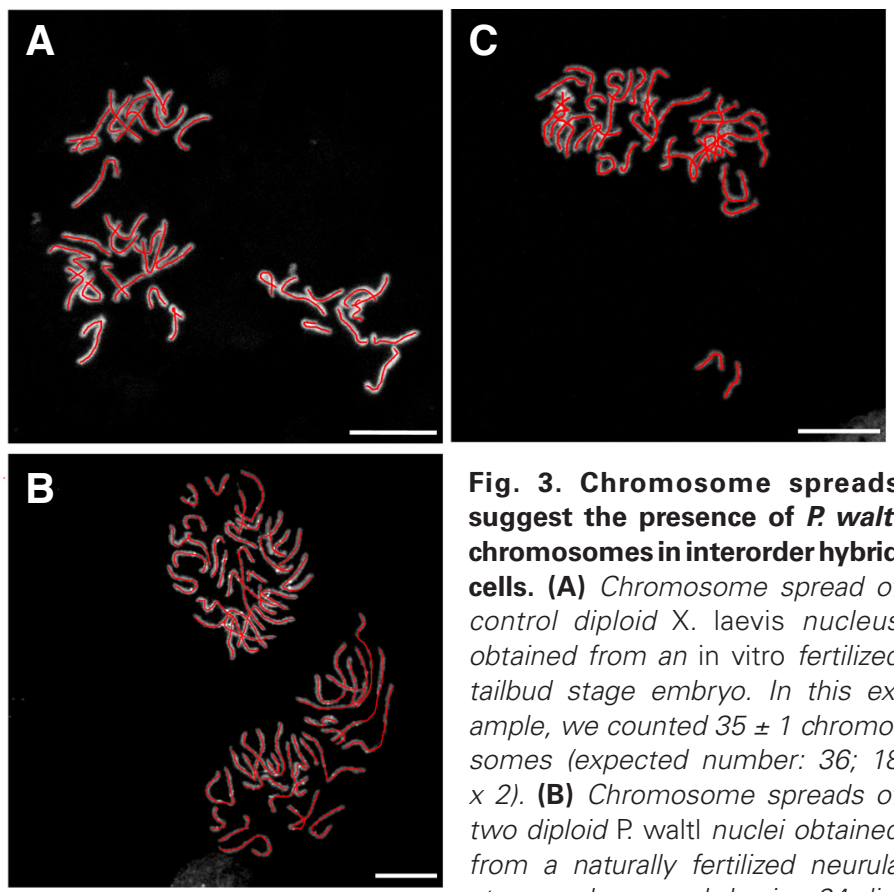

Fig. 3. Chromosome spreads suggest the presence of $P$. waltl chromosomes in interorder hybrid cells. (A) Chromosome spread of control diploid $\mathrm{X}$. laevis nucleus obtained from an in vitro fertilized tailbud stage embryo. In this example, we counted $35 \pm 1$ chromosomes (expected number: 36; 18 $x$ 2). (B) Chromosome spreads of two diploid P. waltl nuclei obtained from a naturally fertilized neurula stage embryo, each having 24 distinct chromosomes (expected number: 24; $12 \times 2$ ). (C) One example of a nucleus isolated from a neurula stage P $\rightarrow$ X NT embryo showed $30 \pm$ 3 chromosomes (expected number: $42 ; 18+(12 \times 2)$ ), suggesting that a number of $\mathrm{P}$. walt chromosomes were retained until this stage in triploid hybrids. Presumed chromosomes were manually highlighted in red. Scale bars in A, C: $10 \mu \mathrm{m}$, and B: $20 \mu \mathrm{m}$.

numbers of a few $X$. laevis genes in the different kinds of embryos analysed here. The results were homogenous across all genes tested, and indicated an expansion in $X$. laevis gene copy number in the order of 10000 -fold in all stage 9 embryos that contained at least one copy of the $X$. laevis genome, but not in $P$. waltl or $P->[X]$ embryos, confirming successful nuclear inactivation of $X$. laevis eggs (Fig. 5). The magnitude of DNA amplification is also consistent with published data (Dawid, 1965). We expected $P->X$ stage 9 embryos to contain only half as many gene copies as $X$. laevis stage 9 diploid controls, but our assay did not detect a significant difference (Fig.5). This is likely due to a limitation in the sensitivity of the assay, which may not have detected a two-fold difference in this case. It is also conceivable that a number of $P$ - $>X$ embryos contained a diploid $X$. laevis genome complement, possibly due either from a failed extrusion of the polar body or to endoreplication before the first cleavage. This possibility however appears unlikely to fully explain the result as such abnormal genome duplications only occur in about $10 \%$ of the cases in $X$. laevis NT embryos (Gurdon, 1959). When we performed the qPCR analysis with $P$.

TABLE 2

\section{DEVELOPMENT AND SURVIVAL OF POST-BLASTULA STAGE NUCLEAR TRANSFER HYBRIDS}

\begin{tabular}{|c|c|c|c|c|c|c|c|}
\hline \multirow[b]{2}{*}{ NT } & \multirow[b]{2}{*}{ Number of grade 5 late blastulae } & \multirow[b]{2}{*}{ Died during gastrulation } & \multicolumn{2}{|c|}{ Late gastrulae } & \multirow[b]{2}{*}{ Died during neurulation } & \multicolumn{2}{|c|}{ Late neurulae" } \\
\hline & & & Abnormal & Normal & & Abnormal & Normal \\
\hline$X->[X]$ & 4 & 0 & 2 & 2 & 1 & 1 & 2 \\
\hline$P->X$ & 16 & 0 & 2 & 14 & 0 & 8 & 8 \\
\hline
\end{tabular}

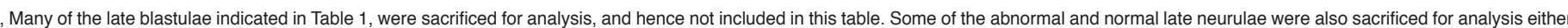

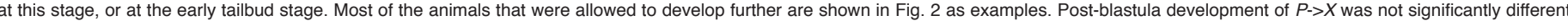
from $X->[X]$ controls $(P=0.5$; Chi Square analysis). 
walt gene specific primers, we again found homogenous results across all genes tested. As expected, $P$. walt/ late blastulae (stage 7 ) and early gastrulae (stage 8 ) respectively had about 7000 -fold and 14000 -fold more copies of each genes than one-cell $P->[X]$ and other controls (Fig. 6). These numbers are consistent with cell count estimates in A. mexicanum embryos (Hara, 1977), a related Caudata species. Interestingly, we found that in both $P->[X]$ and $P->X, P$. walt genes were amplified on average only $\sim 200$-fold by the time control $X$. laevis embryos reached a late blastulae stage (Fig. 6). These results confirm that the $X$. laevis egg cytoplasm is unable to properly expand $P$. walt DNA during development, but that it significantly expands it, and rather homogeneously, at least across the genes/chromosomes tested. Moreover, leaving the maternal genome in the recipient egg rescued the expansion in cell numbers (surface of late blastulae covered by regular cells; Table 1; Fig. 2), but had no significant effect $(P=0.3)$ on $P$. walt DNA expansion (similar gene copy numbers in $P->[X]$ and $P->$ Xlate blastulae; Fig. 6). This indicates that the reduced $P$. walt/DNA copy numbers present in iNT late cybrid blastulae does not result from a reduced rate/success of cell division per se, but from a genuine inability of the $X$. laevis cytoplasm to properly replicate and/or to segregate Pleurodeles DNA/chromosomes into daughters cells during cell division.

\section{Embryonic gene transcription occurs in cybrid embryos}

Embryonic gene transcription has been demonstrated to occur, at least at a global scale, in some lethal cybrids (Fujimoto et al., 2010; Narbonne et al., 2011; Wang et al., 2011), but we do not know whether EGA failure could explain lethality in the most distant cybrid combinations. We have used RT-qPCR to assess gene transcription in interorder hybrid and cybrid NT embryos, using $P$. walt-specific primers. Alimited number of genes were investigated for transcription due to the poor availability of known $P$. walt/gene sequences that are transcribed in late blastula stage embryos. We detected significant transcript levels for GAPDH, Shh, Otx2, and larval $\alpha$-Globin in stage $7 P$. waltl embryos (Fig. 7) and thus pursued the analysis with these four genes in cybrids. Although some iNT embryo samples did not contain detectable levels of transcript for some of the genes tested, transcription from these $P$. walt genes was detected in both $P->[X](4 / 4$ genes) and $P->X$ (3/4 genes) late blastula stage embryos (equivalent to $P$. walt/ St. 7 or $X$. laevis St. 9). Expression levels were however generally reduced ( $~ 10-1000$ fold) as compared to $P$. walt/late blastula stage embryos (Fig. 7). For GAPDH, we have sequenced the amplified RT-qPCR product directly and confirmed a $P$. waltt-specific amplicon origin in 2/2 cybrid embryos (Fig. 8). Since preventing $X$. laevis embryo transcription by the use of $\alpha$-amanitin results in $100 \%$ late blastula stage arrest (Narbonne et al., 2011), EGA was undoubtedly initiated and successful in many of the $P->X$ embryos (Fig. 2; Table 2). As $P$. walt gene expression was not
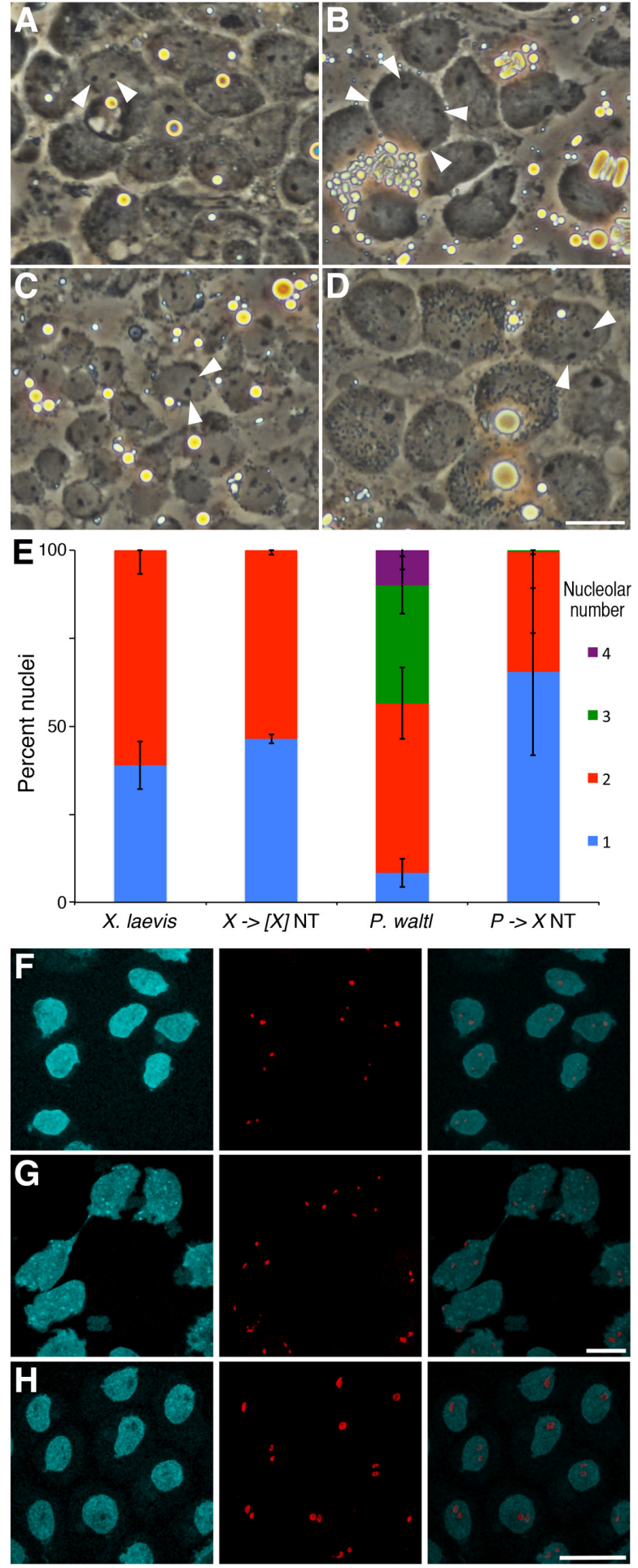

Fig. 4. Nucleolar numbers suggest the presence of $\boldsymbol{P}$ walt/ nucleolar organizing centers in interorder hybrid cells. (A-D) Phase contrast microscopy revealed nucleolar numbers in neurula/tailbud stage nuclei. Arrowheads point at the nucleoli (darker spots) present in one nucleus for each panel as an example. (A) Diploid X. laevis nuclei have 1 or 2 nucleoli per nucleus. (B) Diploid P. waltl nuclei have up to 4 nucleoli per nucleus. (C) X -> (X] nuclei are similar to diploid X. laevis and have up to 2 nucleoli per nucleus. (D) Cells in P -> X triploid hybrids generally have 1 or 2 nucleoli per nucleus, and rarely (0.4\%) 3 nucleoli (not shown). (E) Quantitative representation of phase contrast observations. Nucleolar numbers were averaged over ten embryos for $\mathrm{X}$. laevis and $\mathrm{P}$. walt diploids, 7 for $\mathrm{P} \rightarrow \mathrm{X}$, and 2 for $\mathrm{X} \rightarrow \mathrm{X}$ ]. (F-H) Monoclonal anti-fibrillarin antibodies (red) were used to confirm nucleolar numbers and integrity in (F) diploid X. laevis, (G) diploid P. waltl, and (H) P -> X embryos. DNA (blue) was counterstained with Hoechst. A few nuclei having three distinct fibrillarin-marked spots were also observed in $\mathrm{P} \rightarrow \mathrm{X}$ embryos (not shown), confirming the existence of rare nuclei having three nucleoli per nucleus in these iNT hybrids. Scale bars in (A-D), (F-G) and (H)m $20 \mu \mathrm{m}$. 
increased in $P->X$, compared to $P->[X]$ embryos (Fig. 7), it suggests that the activation of $P$. walt gene transcription by the $X$. laevis egg cytoplasm is independent of the presence of a $X$. laevis genome, or of the global transcriptional activity of the embryo, and that EGA (on $P$. walt genes) occurred equally well in $P->[X]$ and $P \rightarrow X$ iNT embryos.

Although $P$. walt/transcript numbers were dramatically reduced in iNT embryos as compared to $P$. walt diploid late blastulae (Fig.7), $P$. walt DNA levels were also dramatically reduced (Fig. 6). We therefore divided the quantity of transcripts obtained for each gene by the number of $P$. walt/ diploid genome equivalents (based on the qPCR assays) found in each kind of late blastula stage embryos (Fig. 7), in order to determine the level of $P$. walt/ gene transcription per gene copy. Remarkably, the average number of transcripts per gene copy was, in most cases, comparable in $P->[X]$ and $P$. waltl diploid late blastula stage embryos (Fig. 7). Thus, the results overall suggest that the $X$. laevis egg cytoplasm has an inherent inability to efficiently replicate and/or segregate the foreign $P$. walt genome, but that it is able to appropriately activate and transcribe genes from the $P$. walt genome.
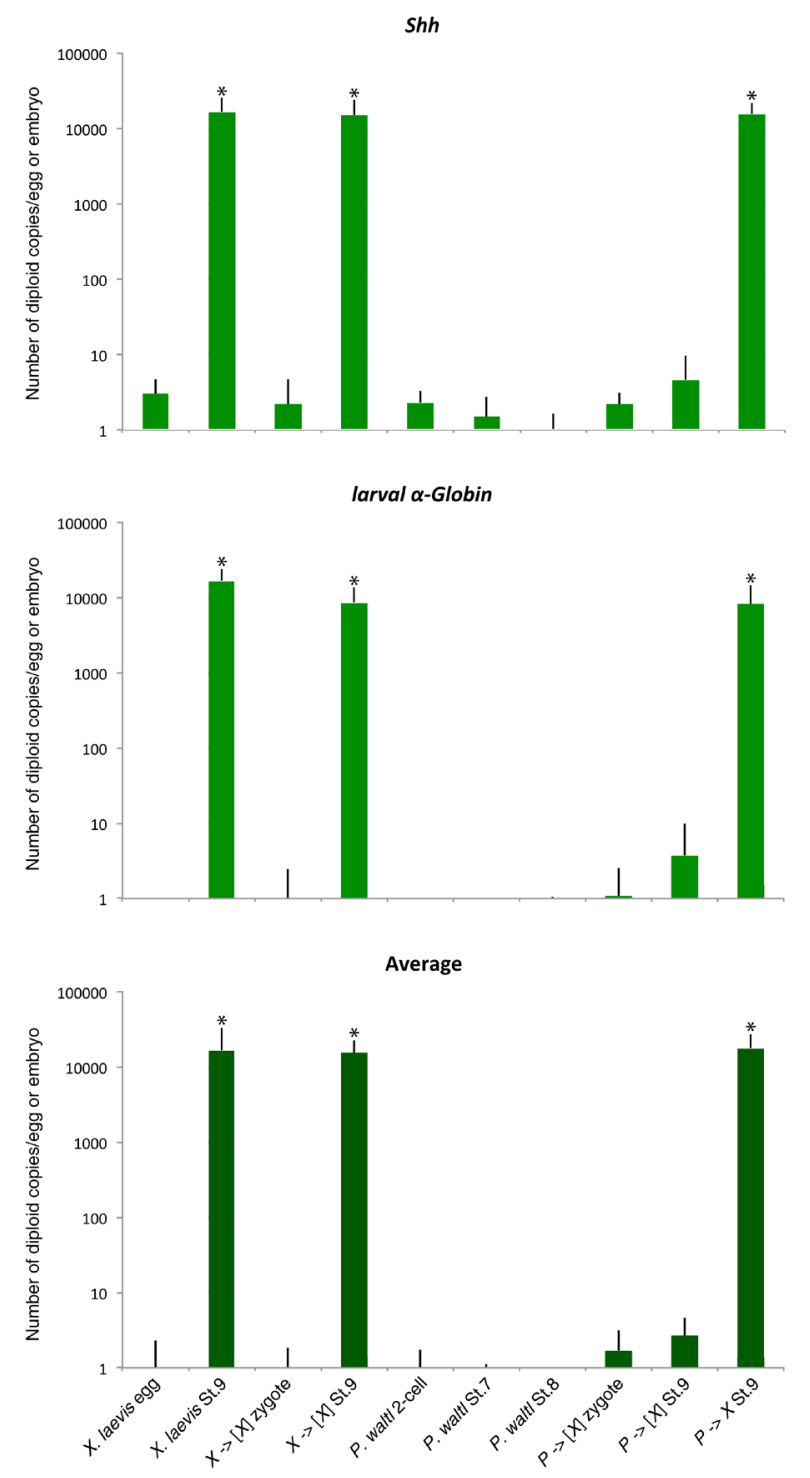

\section{Discussion}

Despite an extensive exploration of the potential of one species' eggs to reprogram and promote the development that is supported by another species nucleus, little is known about the nature of interspecific nucleocytoplasmic incompatibilities (Beyhan et al., 2007; Loi et al., 2011). One certainty that arose from early back-transfer experiments in frogs is that the foreign nucleus may be permanently damaged after undergoing a few rounds of cell division in some, but not all, other species' egg cytoplasm (Moore, 1958; Gurdon, 1962; Hennen, 1974). We have shown here that the genes, and hence presumably also the chromosomes that carry them, of $P$. walt are inefficiently replicated and/or segregated during cell division in embryos with $X$. laevis cytoplasm, in a rather uniform manner. DNA/chromosome loss during cell division in a foreign species cytoplasm is therefore a form of nuclear damage that occurs during the development of cybrid embryos, and may therefore explain some of their lethality and the failure of back-transfer experiments. Which of DNA replication or chromosome segregation defects are responsible for the interspecific nucleocytoplasmic incompatibility
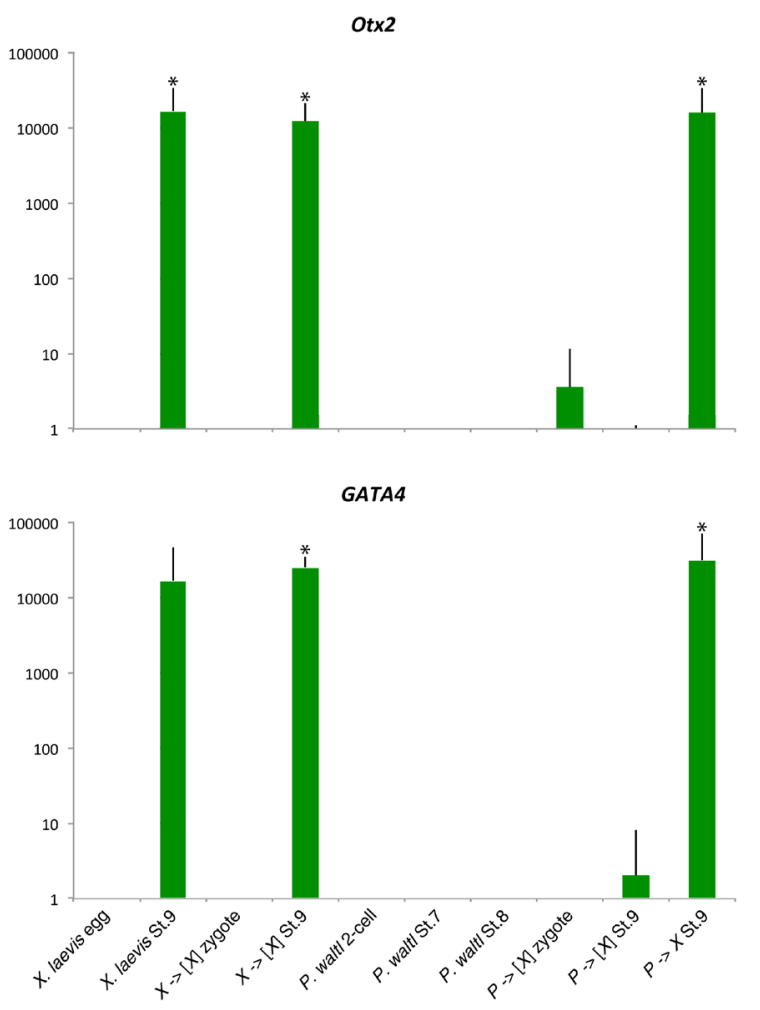

Fig. 5. Normal $X$. laevis DNA amplification in interorder hybrid embryos. DNA was extracted from embryos of the kinds and stages indicated, and subjected to real-time qPCR analysis for selected genes using X. laevis-specific primers. The bottom left graph (dark green) shows an average of all four genes. To convert the relative quantities obtained into a diploid genome equivalent, we have assumed that there were 16700 cells in stage 9X. laevis embryos. This number was inferred from DNA contents in X. laevis embryos (Dawid, 1965). Asterisks (*) indicate statistical significance versus their respective egg/NT zygote/2-cell control ( $P<0.05$; one-tailed $t$-test with unequal variance). Error bars represent the standard deviation. 

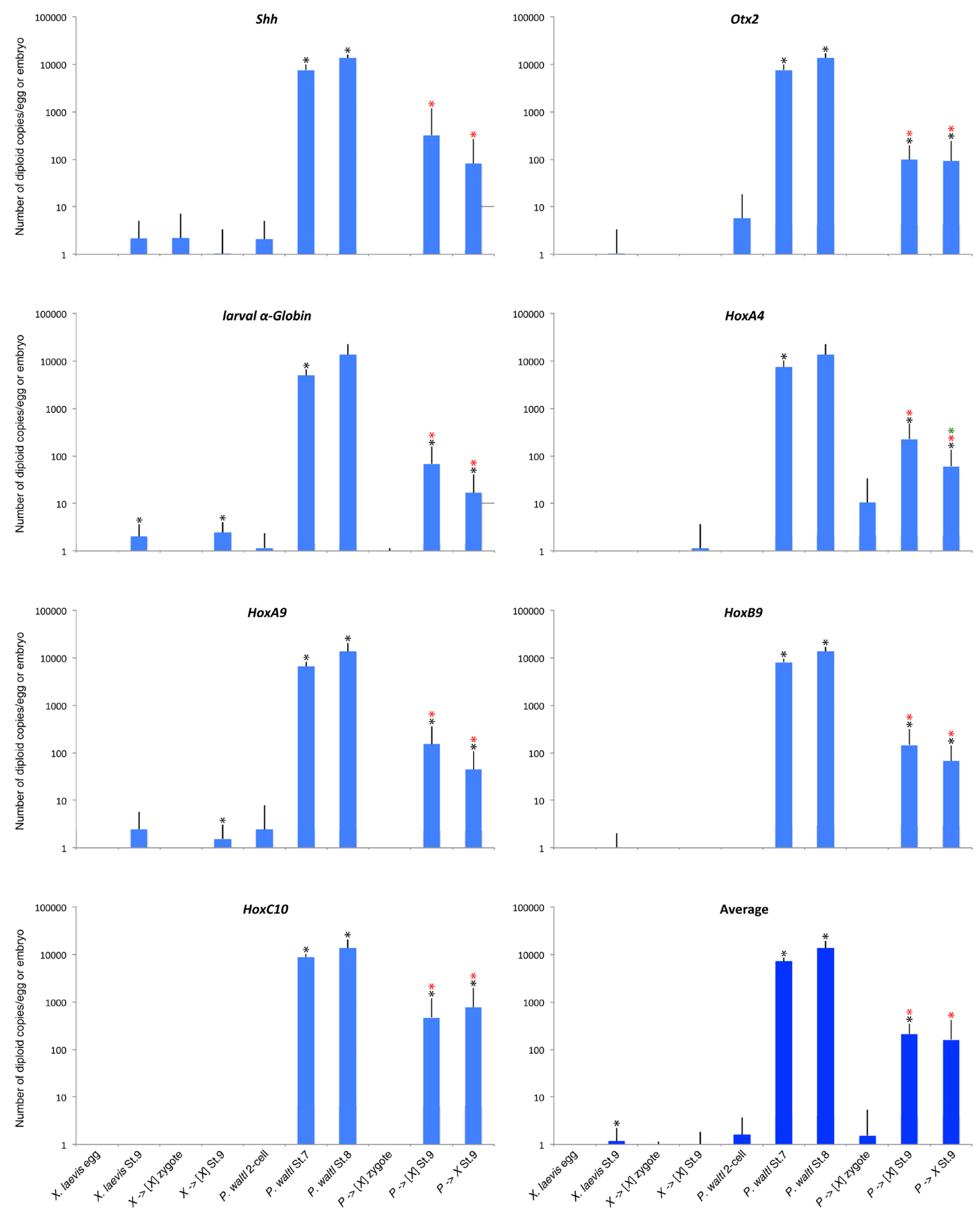

Fig. 6. Poor Pleurodeles DNA amplification in interorder embryos. DNA was extracted from embryos of the kinds and stages indicated, and subjected to real-time qPCR analysis for selected genes using P. waltl-specific primers. The bottom right graph (dark blue) shows an average of all seven genes. To convert the relative quantities obtained into diploid genome equivalents, we assumed that there were 13677 cells in stage 8 P. walt embryos. We could not find a cell number estimate for Pleurodeles, but (Hara, 1977) estimated that there were approximately 13677 cells in axolotl embryos when they begin gastrulation. We then adjusted our real-time PCR data such that stage 8 DNA quantities for each gene corresponded to 13677 diploid genome copies. Black asterisks indicate statistical significance versus their respective egg/NT zygote/2-cell control; red asterisks, versus P. waltl St.7; green asterisks, versus $\mathrm{P} \rightarrow>[X]$ St. $9(P<0.05$; one-tailed t-test with unequal variance). Error bars represent the standard deviation. 
remains unclear, yet the latter appears more likely. Indeed, DNA replication in early $X$. laevis embryos does not depend on specific sequences (Hyrien and Méchali, 1993), and X. laevis egg extracts can replicate mammalian DNA almost as efficiently as $X$. laevis sperm DNA (Dimitrova and Gilbert, 1998; Ganier et al., 2011). Thus, it appears unlikely that $P$. walt I DNA would not be efficiently replicated in $X$. laevis early embryos. Faithful chromosome segregation, on the other hand, requires the recognition of centromeres by kinetochore proteins, and yet the DNA and protein components specific to centromeric chromatin show rapid evolution (Henikoff et al., 2001). Indeed, centromeric DNA sequences have little or no resemblance to each other over relatively short evolutionary times (Birchler et al., 2009). Thus, we would favour the hypothesis that centromeric sequence divergence between $X$. laevis and $P$. walt/ has led to the consequence that centromeric $P$. walt/ DNA is not efficiently recognized by centromeric proteins in the $X$. laevis cytoplasm, leading to an unfaithful segregation of $P$. walt/ chromosomes. This idea is supported by two analyses of interspecific lethal fish hybrids in which uniparental chromosome elimination has been shown to occur during early embryogenesis, although the chromosomes were not always lost from the foreign species (paternal) nucleus (Fujiwara et al., 1997; Sakai et al., 2007). Also, since aberrant chromosome segregation frequently occurs (in $>90 \%$ of the embryos) during early cleavages in same-species SCNT mouse embryos (Mizutani et al., 2012), even a small interspecific incompatibility that would impair foreign species chromosome segregation in cybrid and hybrid cells may be exacerbated in NT embryos.

Defects in EGA have long been thought to be a major cause of interspecies nucleocytoplasmic incompatibilities

Fig. 7. Embryonic gene transcription in interorder cybrid embryos. RNA was extracted from embryos of the kinds and stages indicated, and subjected to RTqPCR analysis for selected genes using P. waltl-specific primers. The top four graphs (turquoise) indicate the amount of $R N A$ relative to the total RNA concentration in each egg or embryo, relative to a stage 7P. waltl embryo (late blastula). The bottom four graphs (dark turquoise) represent the same amounts, except they have been divided by the number of $X$. laevis $X$. laevis egg, St.9) or P. waltl (P. waltl 2-cell, St.7, St.8; $\mathrm{P}->[\mathrm{X}]$ zygote, St.9; $\mathrm{P}->\mathrm{X}$ St.9) diploid genome equivalents present in these embryos (from Figures 5-6). Black asterisks indicate statistical significance versus its $\mathrm{P}->[\mathrm{X}]$ zygote control; red asterisks, versus P. walt St.7; green asterisks, versus $\mathrm{P}->[\mathrm{X}]$ St.9 $(P<0.05$; one-tailed Mann-Whitney test for the top four graphs, and one-tailed t-test with unequal variance for the lower four). Error bars represent the standard deviation. 
$\nabla$

X. laevis TAAAGTTGTTAGCAATGCTTCCTGCACTACAAACTGTCTGGCTCCTCTCGCAAAGGTCATCAACGACAACTTTGGCATTGTTGAGGGACTCATGACAACAGTCCATGCTTTC P. walt l GAAGGTAGTAAGCAACGCCTCCTGCACTACAAACTGTCTGGCTCCTCTGGCTAAGGTCATCCACGACAACTTTCACATCGTCGAGGGTTTGATGACCACTGTACATGCTGTG P. walt embryo

$P \rightarrow[X]$ clone 1

$P \rightarrow[X]$ clone 2 $\Lambda$ GCACTACAAACTGTCTGGCTCCTCTGGCTAAGGTCATCCACGACAACTTTCACATCGTCGAGGGTT GCACTACAAACTGTCTGGCTCCTCTGGCTAAGGTCATCCACGACAACTTTCACATCGTCGAGGGTT GCACTACAAACTGTCTGGCTCCTCTGGCTAAGGTCATCCACGACAACTTTCACATCGTCGAGGGTT

Fig. 8. $\boldsymbol{P}$ walt gene transcription by the $\boldsymbol{X}$. laevis egg cytoplasm. $R T-q P C R$ amplicons from one $\mathrm{P}$. waltl and two $\mathrm{P}->[\mathrm{X}]$ cloned embryo were sent for sequencing using the same P. walt-specific primers as for the qPCR reaction (shown at each ends of the target sequence in the second row). Sequences perfectly matched with the P. walt GAPDH cDNA sequence found in the NCBI database (second row), but not with X. laevis GAPDH cDNA (top row). Nucleotides specific to X. laevis are shown in red and those specific to P. waltl, in blue. Predicted exon/exon boundaries are indicated by green arrowheads, assuming they are conserved between X. tropicalis, X. laevis and P. waltl, and that splicing follows the rules established by (Breathnach and Chambon, 1981).

and cybrid lethality, yet in most studies in which embryonic gene transcription has been assayed, transcript levels were normal for at least some of the genes that were investigated (Wang et al., 2009, 2011; Fujimoto et al., 2010; Narbonne et al., 2011). This contrasts with some earlier studies in which mRNA production was globally reduced in cybrids (Woodland and Gurdon, 1969; Chung et al., 2009), but cell numbers or DNA content of cybrid embryos were not investigated. Our results are thus key in that they provide evidence that gene transcription in early embryos is a highly conserved process, at least in amphibia, and may not therefore be one of the critical limiting factors for cybrid development.

The efficiency of same-species SCNT is low, especially in primates, and a few groups have explored the potential of non-enucleated eggs as NT recipients, as opposed to enucleated eggs. In all cases, the development of the resulting NT triploid or tetraploid embryos was dramatically improved when non-enucleated eggs were used as recipients when compared to enucleated eggs (Sotomaru et al., 2009; Yang et al., 2010; Noggle et al., 2011). Because the maternal nucleus can support early embryonic development on its own to form haploid larvae/blastocysts, it is conceivable that the transplanted somatic nucleus does not fully participate in development during the early steps, although it is eventually completely reprogrammed after culture of the ES cells extracted from the resulting triploid NT blastocyst stage embryos in human (Noggle et al., 2011). A different interpretation is that some key reprogramming factors are so tightly associated with the maternal chromosomes, even during mitosis, that they are inevitably removed from the egg along with the maternal genome, at least with the current enucleation methods (Egli and Eggan, 2010). Here we have compared the developmental potential of iNT embryos using intact and enucleated recipient eggs. Our results showed that the presence of the maternal genome did not improve the replication and/or segregation of the foreign DNA. Also, because the transcription of $P$. walt genes was not improved when the maternal genome was left intact and EGA evidently occurred normally, it proves that embryonic gene transcription initiated normally in cybrids. It is however possible that the transcription of a certain number of genes would remain aberrant in cybrids, due to incompatibilities in their regulatory elements.

\section{Materials and Methods}

\section{Eggs and embryos}

$X$. laevis adults were maintained and eggs were obtained as previously described (Narbonne et al., 2011). P. waltl adults were maintained as described elsewhere (Gallien et al., 1973). All embryos were maintained at $16-18^{\circ} \mathrm{C}$. $X$. laevis egg-based embryos were staged according to (Nieuwkoop and Faber, 1956) and $P$. walt embryos, according to (Shi and Boucaut, 1995).

\section{Nuclear inactivation and nuclear transfer}

Nuclear inactivation and NT were performed essentially as previously described (Elsdale etal., 1960), using endodermal cells from gastrula, neurula or early tailbud stage $X$. laevis or $P$. walt dissociated embryos (depending on availability) as nuclear donors. For NT to non-enucleated $X$. laevis eggs, the jelly was permeabilized by placing the eggs sideways for the $\sim 4$ seconds UV (Hanovia) treatment, ensuring that the white germinal vesicle breakdown spot was not irradiated.

\section{Nucleic acid isolation and qPCR/RT-qPCR}

DNA and RNA were simultaneously isolated from 1 to 3 eggs/embryos at the time, using the AllPrep ${ }^{\circledR}$ DNA/RNA kit (Qiagen), according to the manufacturer's recommendation. In cases where only RNA was isolated, the RNeasy ${ }^{\circledR}$ kit (Qiagen) was instead used. Total RNA concentrations were calculated from their optical density at $260 \mathrm{~nm}$ using a NanoDrop ${ }^{\circledR}$. Reverse transcription and/or qPCR reactions were performed using SYBR Green as previously described (Halley-Stott et al., 2010), with the following primer pairs (5'->3': Forward - Reverse) for P. waltl GAPDH: see (Bascove and Frippiat, 2010); Shh: TCAGCGCCCAGAGAGCTT - CCATTCGCCGGTCCCTAT; Otx2: GCGGGAAGTGAGCTCAGAAA - TGTGGTAGGCGGTGGTGTAA; HoxA4:CGGCGCATGAAATGGAA-GGAGCGCATCTTGGTGTTG; HoxA9: CCGTCCGCCAACTGGTT - GGTGTAAGGGCAGCGTTTTTT; HoxB9: CCCCATGTAGTGTGTCCACAAC - GCGCGCTCCTGGAAGA; HoxC10: TGAATCGCCCCCTTACGAT - CACACAAGACCCACTACAAAACG; larval $\alpha$-Globin:AAACGACATGGAGGCAAGGT-TGCATGTGCTTGGCTGCTT, and for X. laevis GATA4: see (Narbonne et al., 2011); Shh: GACCGCGGCCCATCTAC - ACGACCTGGTGCCGTTGA; Otx2: GCGACCCCCAGGAAACA - CAGTTGGGCCCTGGTAAAAG; larval $\alpha$-Globin: TGTCCCACACTATCCAGGTGACT - GGCTGTGGCATCAAATTCATC. Dissociation curves were checked for each reaction, and when there was no clear peak present at the appropriate melting temperature $\left(+/-0.5^{\circ} \mathrm{C}\right)$ for an RT-PCR amplification product (as in the case of unspecific amplification products), the relative quantity was adjusted to the $-\mathrm{RT}$ value, in order to facilitate data interpretation. Data were averaged across biological replicates (3 to 21 samples per egg/embryo kind), and in cases where there were technical replicates, the highest quantity obtained for each sample was selected for the analysis. Only grade 3 (or better) blastulae (see Table 1) were used for this analysis.

\section{Acknowledgements}

We would like to thank M. Teperek-Tkacz and K. Miyamoto for their useful critical comments on the manuscript, Nigel Garrett for his technical assistance and help, and D. Simpson for his help with frog and newt manipulations and care. P.N. holds a postdoctoral fellowship form the Human Frontier Science Program and is a Junior Research Fellow of Wolfson College. The Gurdon laboratory is supported by grants from the Wellcome Trust and the Medical Research Council.

\section{References}

BAILEY, W.J., KIM, J., WAGNER, G.P., RUDDLE, F.H. (1997). Phylogenetic Reconstruction of vertebrate Hox cluster duplications. Mol Biol Evol 14: 843-853. 
BASCOVE, M., FRIPPIAT, J.-P. (2010). Molecular characterization of Pleurodeles waltl activation-induced cytidine deaminase. Mol Immunol 47: 1640-1649.

BEAUJEAN, N., TAYLOR, J.E., MCGARRY, M., GARDNER, J.O., WILMUT, I., LOI, P., PTAK, G., GALLI, C., LAZZARI, G., BIRD, A., et al., (2004). The effect of interspecific oocytes on demethylation of sperm DNA. Proc Natl Acad Sci USA 101: 7636-7640.

BENTON, M.J., DONOGHUE, P.C.J. (2007). Paleontological evidence to date the tree of life. Mol Biol Evol 24: $26-53$.

BEYHAN, Z., IAGER, A.E., CIBELLI, J.B. (2007). Interspecies nuclear transfer: implications for embryonic stem cell biology. Cell Stem Cell 1: 502-512.

BIRCHLER, J.A., GAO, Z., HAN, F. (2009). A tale of two centromeres-diversity of structure but conservation of function in plants and animals. Funct Integr Genomics 9: 7-13.

BREATHNACH, R., CHAMBON, P. (1981). Organization and expression of eucaryotic split genes coding for proteins. Annu Rev Biochem 50: 349-383.

BRIGGS, R., KING, T.J. (1952). Transplantation of living nuclei from blastula cells into enucleated frogs' eggs. Proc Natl Acad Sci USA 38: 455-463.

CANNON, M.V., DUNN, D.A., IRWIN, M.H., BROOKS, A.I., BARTOL, F.F., TROUNCE, I.A., PINKERT, C.A. (2011). Xenomitochondrial mice: investigation into mitochondrial compensatory mechanisms. Mitochondrion 11: 33-39.

CHUNG, Y., BISHOP, C.E., TREFF, N.R., WALKER, S.J., SANDLER, V.M., BECKER, S., KLIMANSKAYA, I., WUN, W.-S., DUNN, R., HALL, R.M., et al., (2009). Reprogramming of human somatic cells using human and animal oocytes. Cloning Stem Cells 11: 213-223.

DAWID, I.B. (1965). Deoxyribonucleic acid in amphibian eggs. J Mol Bio/12: 581-599.

DIMITROVA, D.S., GILBERT, D.M. (1998). Regulation of mammalian replication origin usage in Xenopus egg extract. J Cell Sci 111: 2989-2998.

EGLI, D., EGGAN, K. (2010). Recipient cell nuclear factors are required for reprogramming by nuclear transfer. Development 137: 1953-1963.

ELSDALE, T.R., GURDON, J.B., FISCHBERG, M. (1960). Adescription of the technique for nuclear transplantation in Xenopus laevis. J Embryol Exp Morphol8: 437-444.

EVANS, B.J., KELLEY, D.B., TINSLEY, R.C., MELNICK, D.J., CANNATELLA, D.C. (2004). A mitochondrial DNA phylogeny of African clawed frogs: phylogeography and implications for polyploid evolution. Mol Phylogenet Evol 33: 197-213.

FUJIMOTO, T., SAITO, T., SAKAO, S., ARAI, K., YAMAHA, E. (2010). Developmental potential of embryonic cells in a nucleocytoplasmic hybrid formed using a goldfish haploid nucleus and loach egg cytoplasm. Int J Dev Biol 54: 827-835.

FUJIWARA, A., ABE, S., YAMAHA, E., YAMAZAKI, F., YOSHIDA, M.C. (1997). Uniparental chromosome elimination in the early embryogenesis of the inviable salmonid hybrids between masu salmon female and rainbow trout male. Chromosoma 106: 44-52.

GALLIEN, C.L., AIMAR, C., GUILLET, F. (1973). Nucleocytoplasmic interactions during ontogenesis in individuals obtained by intra- and interspecific nuclear transplantation in the genus Pleurodeles (urodele amphibian). Dev Biol 33: 154-170.

GANIER, O., BOCQUET, S., PEIFFER, I., BROCHARD, V., ARNAUD, P., PUY, A., JOUNEAU, A., FEIL, R., RENARD, J.-P., MÉCHALI, M. (2011). Synergic reprogramming of mammalian cells by combined exposure to mitotic Xenopus egg extracts and transcription factors. Proc Natl Acad Sci USA 108: 17331 -17336.

GÓMEZ, M.C., POPE, C.E., BIANCARDI, M.N., DUMAS, C., GALIGUIS, J., MORRIS, A.C., WANG, G., DRESSER, B.L. (2011). Trichostatin A modified histone covalent pattern and enhanced expression of pluripotent genes in interspecies black-footed cat cloned embryos but did not improve in vitro and in vivo viability. Cell Reprogram 13: 315-329.

GURDON, J.B. (1959). Tetraploid frogs. J Exp Zool 141: 519-543.

GURDON, J.B. (1960). The developmental capacity of nuclei taken from differentiating endoderm cells of Xenopus laevis. J Embryol Exp Morphol 8: 505-526.

GURDON, J.B. (1962). The transplantation of nuclei between two species of Xenopus. Dev Biol 5: 68-83.

HALLEY-STOTT, R.P., PASQUE, V., ASTRAND, C., MIYAMOTO, K., SIMEONI, I., JULLIEN, J., GURDON, J.B. (2010). Mammalian nuclear transplantation to Germinal Vesicle stage Xenopus oocytes - a method for quantitative transcriptional reprogramming. Methods 51: 56-65.

HAMILTON, L. (1963). An experimental analysis of the development of the haploid syndrome in embryos of Xenopus laevis. J Embryol Exp Morphol 11: 267-278.

HARA, K. (1977). The cleavage pattern of the axolotl egg studied by cinematography and cell counting. Roux Arch Dev Biol 181: 73-87.

HENIKOFF, S., AHMAD, K., MALIK, H.S. (2001). The centromere paradox: stable inheritance with rapidly evolving DNA. Science 293: 1098-1102.

HENNEN, S. (1974). Back-transfer of late gastrula nuclei of nucleocytoplasmic hybrids. Dev Biol 36: 447-451.

HURLEY, I.A., MUELLER, R.L., DUNN, K.A., SCHMIDT, E.J., FRIEDMAN, M., HO, R.K., PRINCE, V.E., YANG, Z., THOMAS, M.G., COATES, M.I. (2007). A new time-scale for ray-finned fish evolution. Proc $R$ Soc B 274: 489-498.

HYRIEN, O., MÉCHALI, M. (1993). Chromosomal replication initiates and terminates at random sequences but at regular intervals in the ribosomal DNA of Xenopus early embryos. EMBO J 12: 4511-4520.

JANVIER, P. (2006). Palaeontology: modern look for ancient lamprey. Nature 443: 921-924.

KENYON, L., MORAES, C.T. (1997). Expanding the functional human mitochondrial DNA database by the establishment of primate xenomitochondrial cybrids. Proc Natl Acad Sci USA 94: 9131-9135.

KIM, T.M., PARK, T.S., SHIN, S.S., HAN, J.Y., MOON, S.Y., LIM, J.M. (2004). An interclass nuclear transfer between fowl and mammal: In vitro development of chicken-to-cattle interclass embryos and the detection of chicken genetic complements. Fertil Steril 82: 957-959.

LEE, H.-S., YU, X.-F., BANG, J.-I., CHO, S.-J., DEB, G.K., KIM, B.-W., KONG, I.K. (2010). Enhanced histone acetylation in somatic cells induced by a histone deacetylase inhibitor improved inter-generic cloned leopard cat blastocysts. Theriogenology 74: 1439-1449.

LEVY, D.L., HEALD, R. (2010). Nuclear size is regulated by Importin $\alpha$ and Ntf2 in Xenopus. Cell 143: 288-298.

LIU, S., ZHOU, Z., CHEN, T., ZHANG, Y., WEN, D., KOU, Z., LI, Z., SUN, Q., CHEN, D. (2004). Blastocysts produced by nuclear transfer between chicken blastodermal cells and rabbit oocytes. Mol Reprod Dev 69: 296-302.

LOI, P., MODLINSKI, J.A., PTAK, G. (2011). Interspecies somatic cell nuclear transfer: a salvage tool seeking first aid. Theriogenology 76: 217-228.

LOUGHLIN, R., WILBUR, J.D., MCNALLY, F.J., NÉDÉLEC, F.J., HEALD, R. (2011). Katanin contributes to interspecies spindle length scaling in Xenopus. Cell 147: 1397-1407.

LUO, Z.-X., YUAN, C.-X., MENG, Q.-J., JI, Q. (2011). A Jurassic eutherian mammal and divergence of marsupials and placentals. Nature 476: 442-445.

MCKENZIE, M., CHIOTIS, M., PINKERT, C.A., TROUNCE, I.A. (2003). Functional respiratory chain analyses in murid xenomitochondrial cybrids expose coevolutionary constraints of cytochrome $b$ and nuclear subunits of complex III. Mol Biol Evol 20: 1117-1124.

MIZUTANI, E., YAMAGATA, K., ONO, T., AKAGI, S., GESHI, M., WAKAYAMA, T. (2012). Abnormal chromosome segregation at early cleavage is a major cause of the full-term developmental failure of mouse clones. Dev Biol 364: 56-65.

MOORE, J.A. (1958). Transplantation of nuclei between Rana pipiens and Rana sylvatica. Exp Cell Res 14: 532-540.

MOORE, J.A., MOORE, B.C. (1953). Studies in the development of frog hybrids. IV. Competence of gastrula ectoderm in androgenetic hybrids. Biol Bull 104: 68-74.

NARBONNE, P., MIYAMOTO, K., GURDON, J.B. (2012a). Reprogramming and development in nuclear transfer embryos and in interspecific systems. Curr Opin Genet Dev 22: 450-458.

NARBONNE, P., HALLEY-STOTT, R.P., GURDON, J.B. (2012b). On the cellular and developmental lethality of a Xenopus nucleocytoplasmic hybrid. Commun Integr Biol 5: 329-333.

NARBONNE, P., SIMPSON, D.E., GURDON, J.B. (2011). Deficient induction response in a Xenopus nucleocytoplasmic hybrid. PLoS Biol 9: e1001197.

NIEUWKOOP, P.D., FABER, J. (Ed.) (1956). Normal table of Xenopus laevis (Daudin): a systematical and chronological survey of the development from the fertilized egg till the end of metamorphosis. North-Holland Pub Co, Amsterdam.

NOGGLE, S., FUNG, H.-L., GORE, A., MARTINEZ, H., SATRIANI, K.C., PROSSER, R., OUM, K., PAULL, D., DRUCKENMILLER, S., FREEBY, M., et al. (2011). Human oocytes reprogram somatic cells to a pluripotent state. Nature 478: 70-75.

NOMIYAMA, H., OSADA, N., YOSHIE, O. (2011). A family tree of vertebrate chemokine receptors for a unified nomenclature. Dev Comp Immunol 35: 705-715.

PICHERAL, B. (1962). Capacities of the nuclei of embryonic endodermal cells to organize a viable germ in the urodele, Pleurodeles waltlii Michah. $C$ R Hebd 
Seances Acad Sci 255: 2509-2511.

RAJARAJAN, K., ENGELS, M.C., WU, S.M. (2012). Reprogramming of mouse, rat, pig, and human fibroblasts into iPS cells. Curr Protoc Mol Biol 97: 23.15.1-23.15.32.

ROELANTS, K., GOWER, D.J., WILKINSON, M., LOADER, S.P., BIJU, S.D., GUILLAUME, K., MORIAU, L., BOSSUYT, F. (2007). Global patterns of diversification in the history of modern amphibians. Proc Natl Acad Sci USA 104: 887-892.

SAKAI, C., KONNO, F., NAKANO, O., IWAI, T., YOKOTA, T., LEE, J., NISHIDAUMEHARA, C., KUROIWA, A., MATSUDA, Y., YAMASHITA, M. (2007). Chromosome elimination in the interspecific hybrid medaka between Oryzias latipes and O. hubbsi. Chromosome Res 15: 697-709.

SHA, H., CHEN, J., CHEN, J., ZHANG, P., WANG, P., CHEN, L., CHENG, G., ZHU, J. (2009). Fates of donor and recipient mitochondrial DNA during generation of interspecies SCNT-derived human ES-like cells. Cloning Stem Cells 11:497-507.

SHI, D.L., BOUCAUT, J.C. (1995). The chronological development of the urodele amphibian Pleurodeles walt (Michah). Int J Dev Biol 39: 427-441.

SHI, L.-H., MIAO, Y.-L., OUYANG, Y.-C., HUANG, J.-C., LEI, Z.-L., YANG, J.-W., HAN, Z.-M., SONG, X.-F., SUN, Q.-Y., CHEN, D.-Y. (2008). Trichostatin A (TSA) improves the development of rabbit-rabbit intraspecies cloned embryos, but not rabbit-human interspecies cloned embryos. Dev Dyn 237: 640-648.

SOTOMARU, Y., HIRAKAWA, R., SHIMADA, A., SHIOZAWA, S., SUGAWARA, A., OIWA, R., NOBUKIYO, A., OKANO, H., TAMAOKI, N., NOMURA, T., et al. (2009). Preimplantation development of somatic cell cloned embryos in the common marmoset (Callithrix jacchus). Cloning Stem Cells 11: 575-583.

SRIRATTANA, K., LAOWTAMMATHRON, C., DEVAHUDI, R., IMSOONTHORNRUKSA, S., SANGMALEE, A., TUNWATTANA, W., LORTHONGPANICH, C., SRIPUNYA, N., KEAWMUNGKUN, K., PHEWSOI, W., et al. (2008). Effect of trichostatin Aon developmental potential of inter-species cloned gaur (Bos gaurus) embryos. Reprod Fertil Dev 21: 126-126.

TECIRLIOGLU, R.T., GUO, J., TROUNSON, A.O. (2006). Interspecies somatic cell nuclear transfer and preliminary data for horse-cow/mouse iSCNT. Stem Cell Rev 2: 277-287.

WANG, K., BEYHAN, Z., RODRIGUEZ, R.M., ROSS, P.J., IAGER, A.E., KAISER, G.G. CHEN, Y., CIBELLI, J.B. (2009). Bovine ooplasm partially remodels primate somatic nuclei following somatic cell nuclear transfer. Cloning Stem Cells 11: 187-202.

WANG, K., OTU, H.H., CHEN, Y., LEE, Y., LATHAM, K., CIBELLI, J.B. (2011). Reprogrammed transcriptome in rhesus-bovine interspecies somatic cell nuclear transfer embryos. PLOS ONE 6: e22197.

WHEATLEY, S.P., O'CONNELL, C.B., WANG, Y.-L. (1998). Inhibition of chromosomal separation provides insights into cleavage furrow stimulation in cultured epithelial cells. Mol Biol Cell 9: 2173-2184.

WOODLAND, H.R., GURDON, J.B. (1969). RNA synthesis in an amphibian nucleartransplant hybrid. Dev Biol 20: 89-104.

YAN, S.Y., MAO, Z.R., YANG, H.Y., TU, M.A., LI, S.H., HUANG, G.P., LI, G.S., GUO, L., JIN, G.Q., HE, R.F. (1991). Further investigation on nuclear transplantation in different orders of teleost: the combination of the nucleus of Tilapia (Oreochromis nilotica) and the cytoplasm of Loach (Paramisgurnus dabryanus). Int J Dev Biol 35: 429-435.

YAN, S.Y., TU, M., YANG, H.Y., MAO, Z.G., ZHAO, Z.Y., FU, L.J., LI, G.S., HUANG G.P., LI, S.H., JIN, G.Q. (1990). Developmental incompatibility between cell nucleus and cytoplasm as revealed by nuclear transplantation experiments in teleost of different families and orders. Int J Dev Biol 34: 255-266.

YANG, H., SHI, L., ZHANG, S., LING, J., JIANG, J., LI, J. (2010). High-efficiency somatic reprogramming induced by intact MII oocytes. Cell Res 20: 1034-1042. 


\section{Further Related Reading, published previously in the Int. J. Dev. Biol.}

Germline stem cells and sex determination in Hydra

Chiemi Nishimiya-Fujisawa and Satoru Kobayashi

Int. J. Dev. Biol. (2012) 56: 499-508

The Dr-nanos gene is essential for germ cell specification in the planarian Dugesia ryukyuensis Haruka Nakagawa, Hirotsugu Ishizu, Ayako Chinone,Kazuya Kobayashi and Midori Matsumoto Int. J. Dev. Biol. (2012) 56: 165-171

Impaired meiotic competence in putative primordial germ cells produced from mouse embryonic stem cells

Marianna Tedesco, Donatella Farini and Massimo De Felici

Int. J. Dev. Biol. (2011) 55: 215-222

A polymorphic, thrombospondin domain-containing lectin is an oocyte marker in Hydractinia: implications for germ cell specification and sex determination

Brahim Mali, R. Cathriona Millane, Günter Plickert, Marcus Frohme and Uri Frank Int. J. Dev. Biol. (2011) 55: 103-108

Generation of germ-line chimera zebrafish using primordial germ cells isolated from cultured blastomeres and cryopreserved embryoids

Yutaka Kawakami, Rie Goto-Kazeto, Taiju Saito, Takafumi Fujimoto, Shogo Higaki, Yoshiyuki Takahashi, Katsutoshi Arai and Etsuro Yamaha

Int. J. Dev. Biol. (2010) 54: 1493-1501

In vitro germ cell differentiation during sex differentiation in a teleost fish

Tohru Kobayashi

Int. J. Dev. Biol. (2010) 54: 105-111

5 yr ISI Impact Factor $(2011)=2.959$

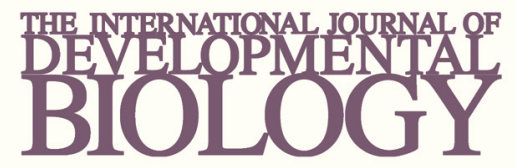

Volume 54 Nos. $6 / 7$
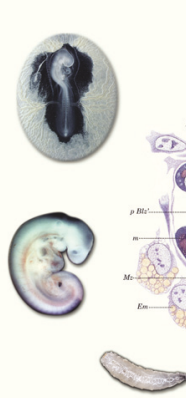

Developmental Hematopoiesis
Special Issue

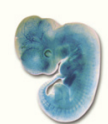

(2) (1) (8)

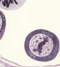

()
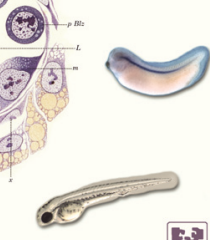

5

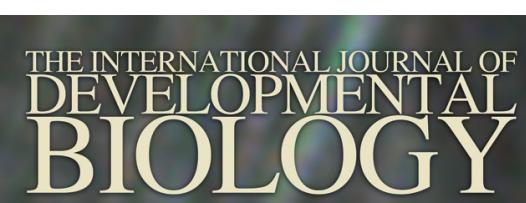

Volume 56 Nos. 1/2/3

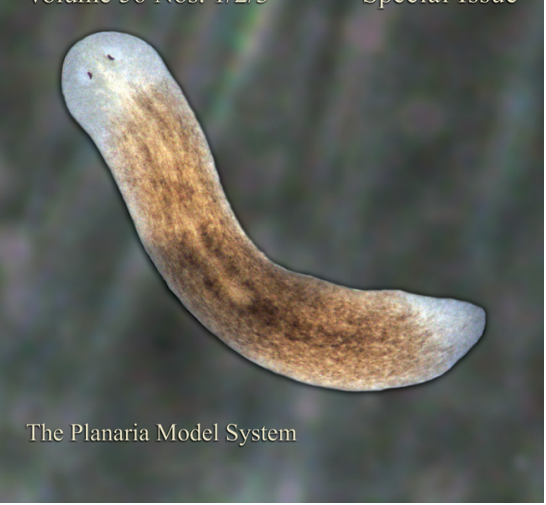

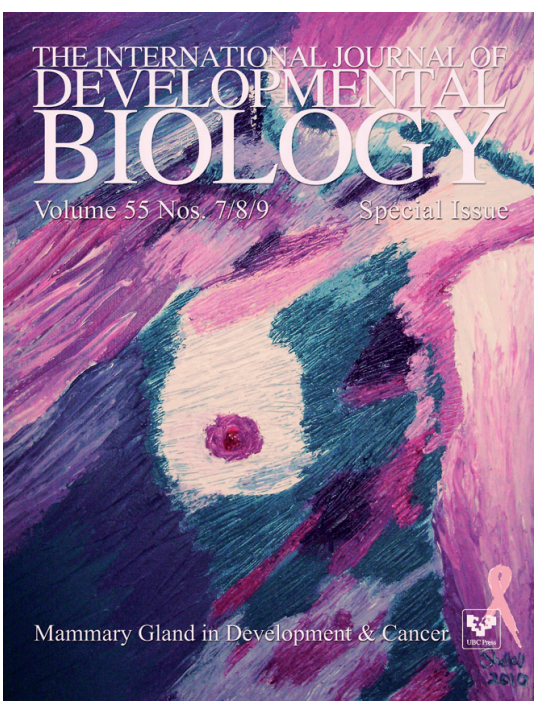

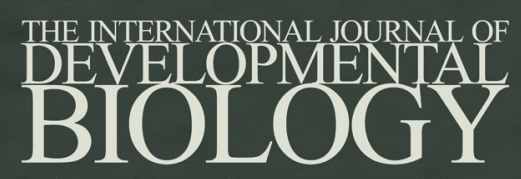

Volume 55 Nos. 4/5

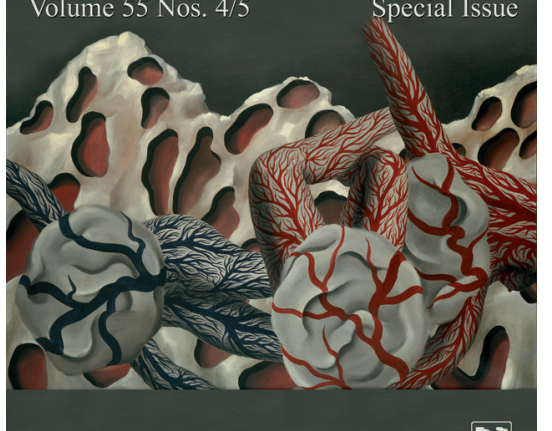

Angiogenesis in Development \& Cance

政 